\title{
Notes on a Certain Marine Diatom*
}

\author{
Masataka KITOU**
}

\section{Introduction}

A certain species of diatom was found among the sea samples which were collected with O-nets ${ }^{* * *}$ in the sea east of Japan by the Ryof $\bar{u}$-maru of the Japan Meteorological Agency in August-September and in November 1955 and with C-nets**** in Enshū-nada by the Atsumi, Ojika and Tsugaru of the Maritime Safety Agency in July-September 1955 from the depths of 100 -m layer to the surface. On the contrary, it was not found among samples collected with buckets at the same stations. So far as the author knows, this diatom has not been described in papers dealing with Japanese waters. This plant is rarely found, but the relationship between its distribution and the sea current is very interesting. As a microphotograph of Cerataulina sp. which was collected by KADO (1954) around the Mukaishima Marine Biological Station of the Hiroshima University bears a close resemblance to the present diatom, they seem to be identical.

\section{Morphological description (Figs. 1-2)}

The valve plane of this diatom is ellipticallanceolate and sightly convex. The apica! axis is $56-63 \mu$ long, the transapical axis $37-45 \mu$, and the pervalval axis 34-55 $\mu$. Cell wall is weakly siliceous. Intercalary bands are not apparent. Each cell has a large and round chromatopiore. Short processes are situated at the ends of apical and transapical axes.

* Received June 5, 1957.

* Japan Meteorological Agency, Tokyo.

*** Used in the Japanese marine meteorological observatories, open type with head cone, 36 $\mathrm{cm}$ in mouth diameter, GG 54 of bolting silk.

**** Used in the Japanese marine meteorological ovservatories, closing type without head cone, $51 \mathrm{~cm}$ in mouth diameter, GG 54 of bolting silk.
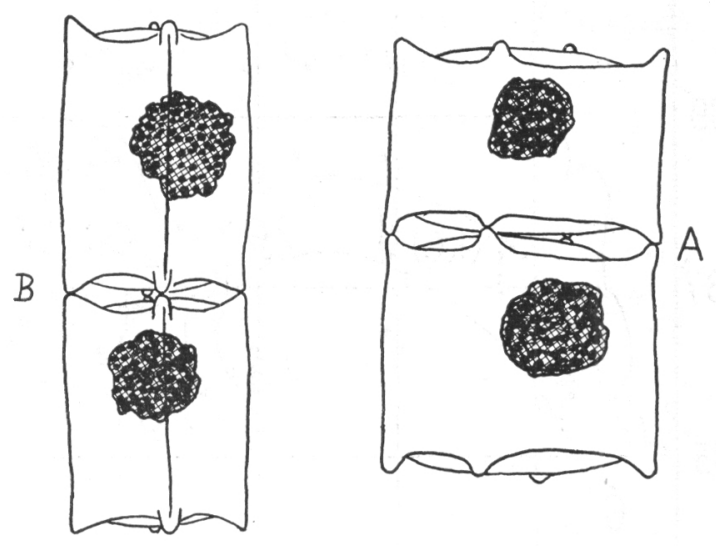

Fig. 1. A certain diatom.

A: Broad girdle view of cell.

B: Narrow girdle view of cell.
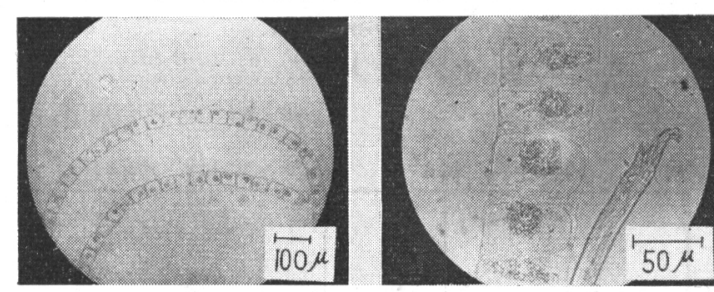

Fig. 2. Microphotograph of a certain diatom.

The cells are joined into chains by the ends of processes. The chains are spirally curved with lanceolate apertures and are 0.74-1.45 $\mathrm{mm}$ in diameter. Often, Licmophora sp. adheres to the plant (Fig. 2).

\section{Distribution (Figs. 3-5)}

The plant occurs in the sea east of Japan and in Enshū-nada around the main Kuroshio stream presumed from the dynamic topographical chart. And it appears also in coastal regions of Enshū-nada. It is known biologically (Kitou, 1956 ; MARumo and Kitou, 1956) and physically (ICHIYe, 1956) that the upper layer of the main Kuroshio stream is mixed with coastal waters, and therefore, 


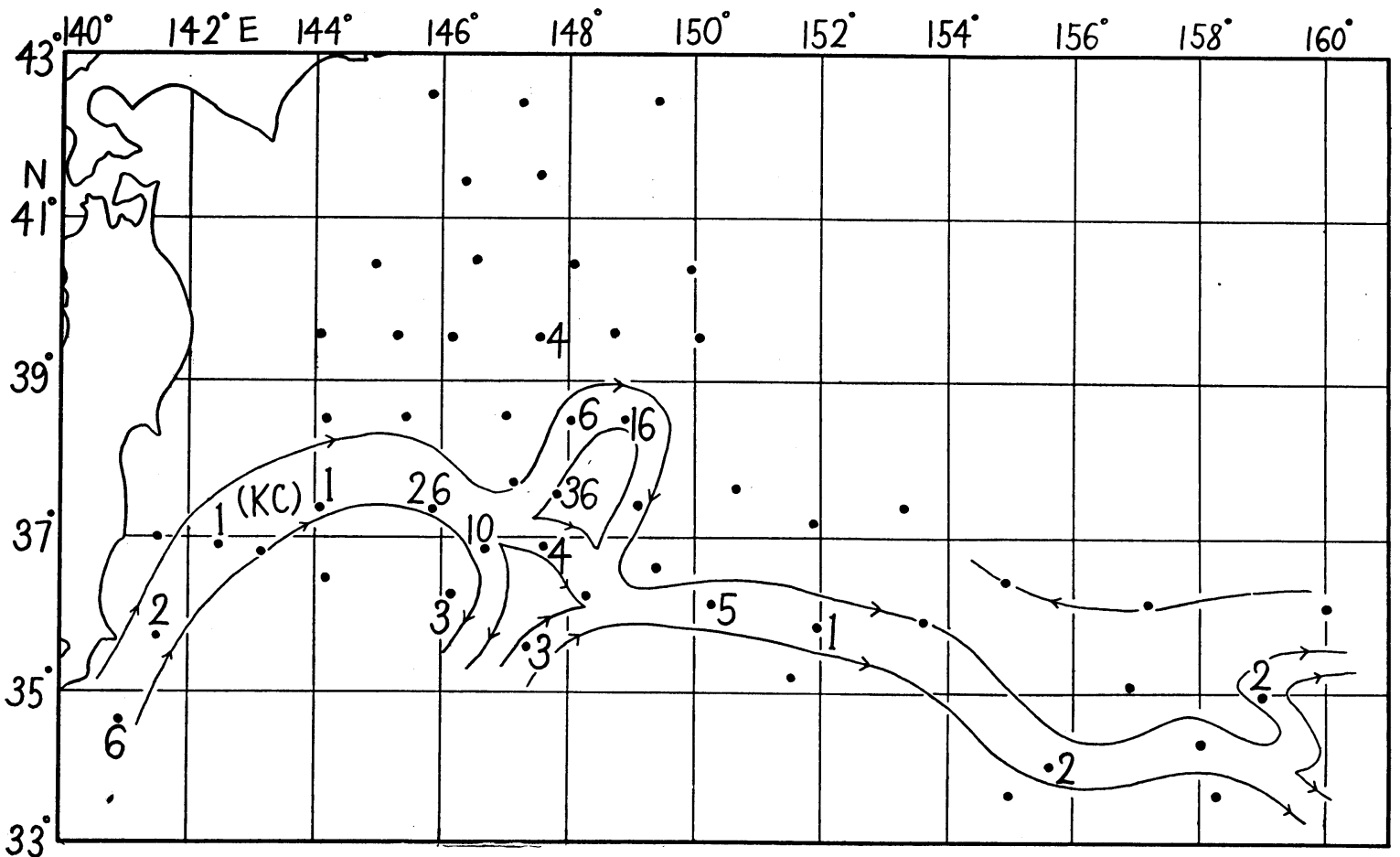

Fig. 3. Observational stations and number of chains contained in $10 \mathrm{~m}^{3}$ sea water in the sea east of Japan in August-September 1955. KC: Kuroshio Current.

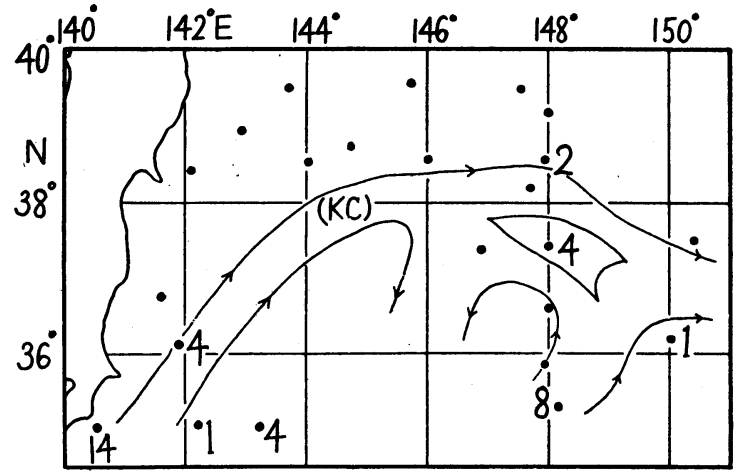

Fig. 4. Observational stations and number of chains contained in $10 \mathrm{~m}^{3}$ sea water in the sea east of Japan in November 1955. KC: Kuroshio Current.

the distribution of the plant stated above means that it is originated in coastal waters. Scarceness of the samples makes it very difficult to decide here whether the distributions of the plant are obtained accidentally

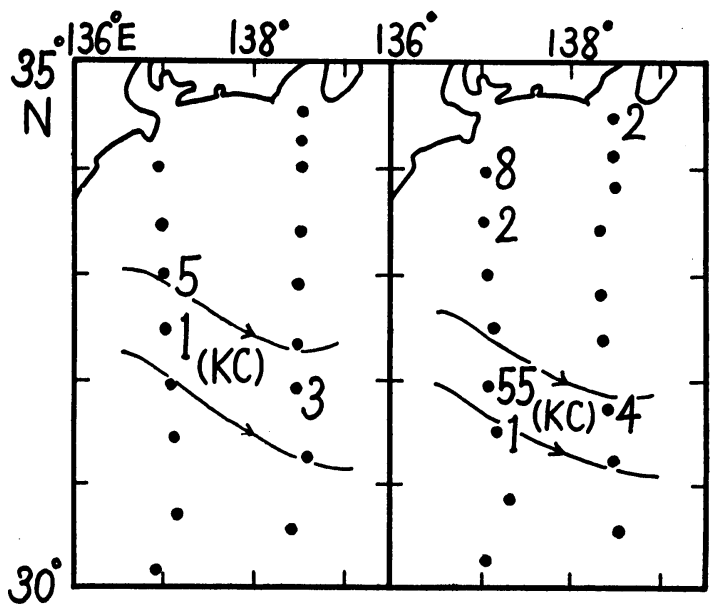

Fig. 5. Observational stations and number of chains contained in $10 \mathrm{~m}^{3}$ sea water in Enshū-nada in July-September 1955. KC: Kuroshio Current.

or not. If future surveys should have ascertained that this plant occurs usually around the main Kuroshio stream and in coastal regions, this plant will become a useful species to indicate coastal waters. 


\section{References}

ICHIYE, T., 1956 :

"On the Annual Variation of Chlorinities at the Upper Layer of the Kuroshio". Oceano. Mag., 7, 2.

KADO, Y., 1954 :

"The Seasonal Change of Plankton and Hydrography of the Neighbouring Sea of Mukaisima". Jour. Sci. Hiroshima Univ., 15, 6.
KITOU, M., 1956 :

"The Correlation of the Oceanographical Conditions to the Distributions of Plankton Larvae of Littora! Benthos in Enshū-nada" (in Japanese). Jour. Oceanogr. Soc. Japan, 12, 2.

MARUMO, R., and M. KITOU, 1956 :

"Distribution of Pelagic Larvae of Littoral Animals in the Open Sea" (in Japanese). Bull. Jap. Soc. Sci. Fish., 22, 4. 